\title{
Questionnaire-based evaluation of everyday competence in older adults
}

\author{
This article was published in the following Dove Press journal: \\ Clinical Interventions in Aging \\ 25 January 2011 \\ Number of times this article has been viewed
}

\author{
Tobias Kalisch ${ }^{1}$ \\ Julia Richter ${ }^{3}$ \\ Melanie Lenz' \\ Jan-Christoph \\ Kattenstroth ${ }^{2}$ \\ Izabela Kolankowska ${ }^{2}$ \\ Martin Tegenthoff' \\ Hubert R Dinse ${ }^{2}$ \\ 'Department of Neurology, \\ BG-Kliniken Bergmannsheil, \\ ${ }^{2}$ Neural Plasticity Lab, Institute \\ for Neuroinformatics, Department \\ of Theoretical Biology, ${ }^{3}$ Faculty of \\ Psychology, Department of Methods, \\ Diagnostics and Evaluation, Ruhr- \\ University Bochum, Germany
}

Background: Gerontological research aims at understanding factors that are crucial for mediating "successful aging". This term denotes the absence of significant disease and disabilities, maintenance of high levels of physical and cognitive function, and preservation of social and productive activities. Preservation of an active lifestyle is considered an effective means through which everyday competence can be attained. In this context, it is crucial to obtain ratings of modern day older adults' everyday competence by means of appropriate assessments. Here, we introduce the Everyday Competence Questionnaire (ECQ), designed to assess healthy older adults' everyday competence.

Methods: The ECQ includes 17 items, covering housekeeping, leisure activities, sports, daily routines, manual skills, subjective well-being, and general linguistic usage. The ECQ was administered to a population of 158 healthy subjects aged 60-91 years, who were divided into groups on the basis of their physical activity. These groups were community-dwelling subjects, those living independently and having a sedentary lifestyle, those living independently but characterized by a general lifestyle without any noteworthy physical activity, and those living independently and exercising regularly. Age, gender, and education levels were balanced between the groups.

Results: Using the ECQ, we could identify and distinguish different everyday competence levels between the groups tested: Subjects characterized by an active lifestyle outperformed all other groups. Subjects characterized by a general lifestyle showed higher everyday competence than those with a sedentary lifestyle or subjects who needed care. Furthermore, the ECQ data showed a significant positive correlation between individual physical activity and everyday competence.

Conclusion: The ECQ is a novel tool for the questionnaire-based evaluation of everyday competence among healthy subjects. By including leisure activities, it considers the changed living conditions of modern-day older adults.

Keywords: successful aging, everyday competence, questionnaire-based evaluation

\section{Background}

In the past few decades we have experienced dramatic changes in the age structure of human populations, especially in industrialized countries. These changes are characterized by an increasing probability of reaching old and very old age. ${ }^{1-3}$ As a multidimensional reality of life, aging is difficult to define simply. ${ }^{4}$ The World Health Organization defines aging as a "process of progressive change in the biological, psychological and social structure of individuals". ${ }^{5}$ From a biological standpoint, aging is often used synonymously with the term senescence, defined as "a biological process of dysfunctional change by which organisms become less capable of maintaining
Correspondence: Tobias Kalisch Abt für Neurologische Traumatologie und Neurorehabilitation, Neurologische Universitätsklinik, BG-Kliniken Bergmannsheil, Bürkle-de-la-Camp-Platz I, D-44789 Bochum, Germany

Tel +4902343222168

Fax +4902343204931

Email tobias.kalisch@rub.de 
physiological function and homeostasis with increasing survival". ${ }^{6}$ Collectively, these definitions and others reflect the difficulty in defining aging precisely. ${ }^{4}$ Generally aging is associated with progressive functional loss in perception, cognition, and memory, ${ }^{7}$ as well as a deterioration of physiological capacities, such as muscle strength, aerobic capacity, and neuromotor coordination. ${ }^{8}$ Although these changes are highly variable, there is a high probability that older adults suffer from age-related dysfunctions, ${ }^{9}$ which challenge their independence in everyday life. These increased dysfunctions emphasize the need to understand better the mechanisms of the human aging process on the one hand and to develop strategies to maintain health and functional independence on the other hand. Independence in everyday life is regarded as a crucial feature for "successful aging", which is defined as the absence of significant disease and disabilities, maintenance of high levels of physical and cognitive function, and preservation of social and productive activities. ${ }^{10,11}$ Because the loss of independence is inevitably linked to institutionalization, it is regarded as an important socioeconomic factor, especially considering the anticipated demographic changes in industrial civilizations. ${ }^{1-3}$ There is now agreement that in addition to cardiovascular fitness, ${ }^{12-14}$ cognitive training,,${ }^{15,16}$ and healthy nutrition, ${ }^{17,18}$ an active lifestyle is an important prerequisite for healthy aging, as expressed in the gerontological slogan "use it or lose it".

\section{Evaluation of everyday competence in old age}

Everyday competence refers to "a person's ability to perform, when necessary, a broad array of activities considered essential for independent living, even though in daily life the individual may not perform these tasks on a regular basis or may only perform a subset of these activities". ${ }^{21}$ However, the term "everyday competence" is often interpreted differently. Many investigations refer to instrumental activities of daily living (IADL), eg, handling finances, taking medication, using the phone, shopping, preparing meals, housekeeping, and navigating large distances outdoors. ${ }^{22}$ Others favor the analysis of leisure activities and the social behavior of older adults. ${ }^{23}$ Accordingly, the concept of everyday competence is not clearly defined, but it provides a perspective on the life of older adults. ${ }^{24}$

In the past few decades, a number of studies have investigated the everyday competence of older adults..$^{22,24-32}$ Some of these studies were not only motivated by the current demographic changes and the general need to understand the mechanisms and consequences of the human aging process, but also by a persisting discrepancy between the results of laboratory-based experiments that showed age-related loss of various functions and the often contradictory and unexpected high everyday competence of subjects observed in their private surroundings. ${ }^{28,33}$ Performance-based measures use functional tasks in a standardized format. ${ }^{34} \mathrm{~A}$ known problem of these tests is that they assess the abilities of subjects under directed optimal conditions rather than their actual habits in everyday life. ${ }^{35}$ Furthermore, it is known that sometimes it is not a lack of capacity that hinders the performance of older adults, but a deficiency in drive and motivation to initiate certain actions in everyday life conditions. ${ }^{36}$ Hence, performance-based measures may lead to an incorrect estimation of older adults' abilities in their private surroundings. Another method to measure functional abilities in older adults and to gather reliable data about everyday behavior is direct observation. ${ }^{37,38}$ However, direct observation might be biased by the subjects' knowledge about being monitored. Finally, self and collateral reports allow for a quick assessment of functional abilities in older adults. The main limitation of this method is the often reduced ability of older adults to recall details of their everyday life accurately. ${ }^{39}$ This limitation can, however, be counterbalanced by an elaborate method of asking for relevant details concerning activities of daily living, thereby possibly improving the quality of the data obtained.

\section{Motivation for developing the ECQ}

In the past few years, we have investigated sensorimotor abilities in older adults to study age-related degradation in sensorimotor performance. Further, we developed interventional measures to ameliorate age-related decline in sensorimotor performance and cognition. ${ }^{40-44}$ During the assessment of sensorimotor performance, we noticed a substantial interindividual variation, indicating that the decline in performance could not be attributed to age alone. Studies on use-dependent plasticity imply that maintaining performance requires regular practice and use. ${ }^{45,46}$ For example, reduced use because of immobilization of a limb leads to rapid deterioration of cortical representations, which harms associated perception and behavior. ${ }^{47,48} \mathrm{It}$ is, therefore, conceivable that aging reduces everyday life activities to a varying extent, and this contributes to differently impaired sensorimotor abilities. To obtain standardized information about the interdependencies between individual lifestyles and conditions of everyday life promptly on the one hand, and levels of sensorimotor performance on the other, we developed a questionnaire that covers housekeeping, leisure activities, 
sports, daily routines, manual skills, subjective well-being, and general linguistic usage.

\section{Methods Subjects}

The study is based on data collected from 158 subjects (males 55, females 103). Subjects were recruited from a subject registry, newspaper advertisements, and older adult housing sites. The mean age of the subjects was $72.5 \pm 6.1$ years (range 60-91 years). All subjects were neurologically healthy. Medication with central nervous effects in the present or reported history was a criterion for exclusion. Subjects with an unclear anamnesis or medical history underwent an examination by a clinical neurologist to ensure neurological health. Basic cognitive abilities were assessed using the Mini-Mental State Examination (MMSE). ${ }^{49,50}$ The inclusion criterion for participation was a score of at least 27 points. This regulation did not apply to Group 4 (nursing care), where subjects reached only $23.7 \pm 3.7$ points. All the subjects gave their written informed consent before participating in the study. The study was approved by the local Ethics Committee of the Ruhr University of Bochum. All the percentages presented in the text or tables are with reference to the complete cohort of 158 subjects. The subgroup arrangements of the cohort are presented in Table 1, and Table 2 lists the education levels of all the subjects.

Differences between subjects (age, education, and gender) in all the groups were analyzed using analysis of variance (ANOVA). Results showed significant $F$ statistics for the main independent variable (group): $F_{(3,154)}=35.446 ; P \leqslant 0.000$ $\left(R^{2}=40.8 \%\right)$. The results of a Chi-square test revealed no confounds between the subjects' gender and their group membership $\left(\chi_{(3)}^{2}=5.027, P=0.170\right)$. On the other hand,
ANOVA revealed significant confounds between the group membership of the subjects and the individual level of education $\left(F_{(156)}=10.870 ; P \leqslant 0.001\right)$ and age $\left(F_{(154)}=10.627\right.$; $P \leqslant 0.001)$. Based on these findings, we calculated an analysis of covariance (covariates age and education) that supported a significant main effect for group $\left(F_{(151)}=21.801\right.$; $P \leqslant 0.001)$.

\section{Instrument development and data administration}

For the construction of the ECQ, we hypothesized that leisure activities might be a valuable indicator of everyday competence. Because life span and health conditions are positively affected by modern medical care, older adults have more time available for hobbies, cultural, and social activities, and sports. ${ }^{24}$ The questionnaire consisted of 17 items (Table 3), where items 1-16 were based on the self-report of the subjects, while item 17 ("fluency of speech") was based on the ratings of the experimenter. All subjects were asked to respond to the questions in as much detail as possible, thereby giving insight into their habits and living conditions. The experimenter converted the answers into scores using an item-specific scale. The items referred to domains such as leisure activities, sports, subjective well-being, and linguistic abilities. IADLspecific domains such as housekeeping, daily routine, manual skills, and mobility were also considered in the questionnaire. All the items and the corresponding rating scales are listed in Table 3.

\section{Discriminatory power and internal consistency}

The internal consistency (estimated by calculation of Cronbach's coefficient alpha) of all the items was 0.835 .

Table I Housing and living conditions. Subjects were divided into four groups representing different lifestyles in terms of independence, social contacts, and physical activity

\begin{tabular}{lll}
\hline Group & Lifestyle & Explanation \\
\hline $\mathbf{I}$ & "General" & Independently living subjects with regular social \\
$(\mathrm{n}=5 \mathrm{I})$ & contacts and agile lifestyle. No workout. \\
$\mathbf{2 a}$ & "Active" & Independently living subjects with regular social \\
$(\mathrm{n}=30)$ & & contacts and active lifestyle. Regular amateur dancing. \\
$\mathbf{2 b}$ & & Independently living subjects with regular social \\
$(\mathrm{n}=22)$ & contacts and active lifestyle. Regular workout. \\
$\mathbf{2 c}$ & & Independently living subjects with regular social \\
$(\mathrm{n}=21)$ & contacts and active lifestyle. Irregular workout. \\
$\mathbf{3}$ & "Sedentary" & Subjects living in senior residences. Reduced social \\
$(n=27)$ & contacts. No workout. \\
$\mathbf{4}$ & "Nursing care" & Subjects in need of care living in a nursing home. Very \\
$(n=7)$ & limited social contacts. Almost static lifestyle.
\end{tabular}


Table 2 Education of the subjects: overview of the education level, years in professional training, and duration of retirement for all subjects

\begin{tabular}{llll}
\hline $\begin{array}{l}\text { School form (according } \\
\text { to the German school } \\
\text { system) }\end{array}$ & $\begin{array}{l}\text { Usual } \\
\text { duration } \\
\text { (years) }\end{array}$ & $\begin{array}{l}\text { Average } \\
\text { duration } \\
\text { (years) }\end{array}$ & $\begin{array}{l}\text { \% of } \\
\text { cohort }\end{array}$ \\
\hline "Grundschule" & 4 & 4 & 100.0 \\
"Volksschule" & 8 & 7.9 & 63.1 \\
"Hauptschule" & 9 & 8.8 & 6.4 \\
"Realschule" & 10 & 9.5 & 15.3 \\
"Gymnasium" & 13 & 12.8 & 14.6 \\
Professional training & 3 & 3.2 & 72.6 \\
Retirement & - & 17.2 & 89.8 \\
\hline
\end{tabular}

Two out of 17 items showed item-total correlations below 0.3 (item 8: 0.285, item 14: 0.243). Because it had very low discriminatory power $(0.082)$, a previously used item ("Do you solve crossword puzzles or brain teasers?") was omitted from the final version of the questionnaire. A further exclusion of items 8 and 14 did not improve the internal consistency $(r=0.843)$. Therefore, the final 17-item version of the ECQ was used for all subsequent analyses. Analysis of test-retest reliability revealed high consistency (Cronbach's alpha 0.844).

Because the maximal number of points varied between 2 and 5, we normalized the scores of every single item to ensure that all items had the same impact on the total scale of the questionnaire. This was done by dividing the individual number of points obtained by a subject per item by the maximum possible score of the given item. Normalized data revealed similar results in terms of internal consistency (Cronbach's alpha 0.843).

\section{Construct validation}

A subsample of subjects $(\mathrm{n}=83 ; 37 \%$ in Group $1,51 \%$ in Group 2, 4\% in Group 3, and 8\% in Group 4) took the MMSE. ${ }^{49}$ Within the narrow distribution of the obtained MMSE scores, which were not normally distributed $\left(_{(\mathrm{KS})}=2.064 ; P \leqslant 0.001\right)$, we found a significant correlation between ECQ scores and the scores obtained in the MMSE (Spearman correlation, $r=0.316 ; P=0.004$ ).

Another subsample of subjects ( $\mathrm{n}=40 ; 25 \%$ in Group 1, $70 \%$ in Group 2, 5\% in Group 3, and 0\% in Group 4) took the Nürnberger-Alters-Alltagsaktivitäten-Skala $\left(\mathrm{NAA}^{51}\right.$ ), which consists of 20 questions designed to collect information about restrictions in everyday activities. High scores in the NAA reflect substantial restrictions in everyday life. We found a significant negative correlation between the NAA scores and the ECQ scores (Pearson correlation, $r=-0.320$; $P=0.044)$.

\section{Factor analysis of used items}

A factor analysis for all items of the ECQ was conducted using main component analysis with varimax rotation. The KaiserMyer-Olkin value was satisfactory, namely, 0.847 (refer to previously published research $\left.{ }^{52}\right)$. Bartlett's test revealed a significant result $\left(\chi_{(136)}^{2}=859.257, P \leqslant 0.001\right)$. The measure of sampling adequacy for almost all items was distributed between 0.7 and 0.9. As an exception, the value for item 14 was 0.653 . Nevertheless, no further item had to be excluded from the analysis (see previous reports ${ }^{53,54}$ ). Using a scree plot analysis, we extracted a four-factor structure from the data. By means of the four factors, $56.1 \%$ of the variance within the collected ECQ data could be explained (Table 4).

\section{Results \\ Analysis of group-specific differences in everyday competence}

The data obtained from the ECQ were normally distributed $\left(Z_{(\mathrm{KS})}=0.624, P=0.831\right)$. Homogeneity of variance was examined using Levene's test $\left(F_{(154)}=2.512, P=0.061\right)$. In order to analyze possible group-specific differences, we pooled the data of subjects in Group 1 (general lifestyle), 2 (active lifestyle), 3 (sedentary lifestyle), and 4 (nursing care) without differentiating between the subgroups of Group 2. Using an ANOVA (the inter-subject factor was score, the between-subject factor was group) we found a significant main effect in the data, $F_{(3,154)}=35.466, P \leqslant 0.001$ $\left(\mathrm{R}^{2}=40.9 \%\right)$. Data revealed top scores (11.17 \pm 2.58 points $)$ for the subjects of Group 2 (active lifestyle), $9.48 \pm 1.67$ points for the subjects of Group 1 (general lifestyle), $7.91 \pm 1.89$ points for the subjects of Group 3 (sedentary lifestyle), and the lowest scores ( $3.69 \pm 1.47$ points) for the subjects of Group 4 (nursing care).

Using post hoc tests (Bonferroni), we found significant differences in ECQ performance of our subjects (see Figure 1). Subjects from Group 2 (active lifestyle) outperformed subjects from all other groups $(P \leqslant 0.001)$. Subjects from Group 1 (general lifestyle) had significantly higher scores on the ECQ than subjects from Group 3 (sedentary lifestyle, $P=0.014$ ) and Group 4 (nursing care, $P \leqslant 0.001$ ). Finally, subjects from Group 3 (sedentary lifestyle) had significantly higher scores than subjects from Group 4 (nursing care, $P \leqslant 0.001)$.

\section{Differences in everyday competence in Group 2 (active lifestyle)}

According to the individual activities of subjects in Group 2, we divided the subjects into three subgroups, 
Table 3 Everyday Competence Questionnaire: the questionnaire consisted of 17 items with one specific question per item (additional information for the investigator is given in parentheses)

\begin{tabular}{|c|c|c|c|c|}
\hline Item & Questions & Domain & Ranking & Score (points) \\
\hline \multirow[t]{5}{*}{1} & \multirow{5}{*}{$\begin{array}{l}\text { "What kind of hobbies do you have?" } \\
\text { (self-contained, not with other people) } \\
\text { (jump to other questions if necessary) }\end{array}$} & \multirow[t]{5}{*}{ Isa } & Mentally and physically challenging & 3 \\
\hline & & & Mentally or physically challenging & 2 \\
\hline & & & Other (television etc) & I \\
\hline & & & None & 0 \\
\hline & & & $\begin{array}{l}\text { Up to I point bonus for very } \\
\text { challenging activities }\end{array}$ & \\
\hline \multirow[t]{4}{*}{2} & "How do you manage housekeeping?" & $\mathrm{hk} / \mathrm{dr}$ & Independently & 3 \\
\hline & \multirow[t]{3}{*}{ (estimate the need for help) } & & With a little support & 2 \\
\hline & & & With major support & I \\
\hline & & & Dependent & 0 \\
\hline \multirow[t]{4}{*}{3} & "How do you manage shopping?" & $\mathrm{hk} / \mathrm{dr}$ & Independently & 3 \\
\hline & \multirow[t]{3}{*}{ (estimate the need for help) } & & Supported by partner & 2 \\
\hline & & & Only with the support of partner & I \\
\hline & & & Dependent (delivery service) & 0 \\
\hline \multirow[t]{3}{*}{4} & \multirow{3}{*}{$\begin{array}{l}\text { "Do you cook at home?" } \\
\text { (estimate the need for help) }\end{array}$} & $\mathrm{hk} / \mathrm{dr}$ & Independently and regularly & 2 \\
\hline & & & Occasionally & I \\
\hline & & & No (meals on wheels, partner) & 0 \\
\hline \multirow[t]{6}{*}{5} & "How do you commute?" & $\mathrm{m}$ & Bike & 3 \\
\hline & \multirow[t]{5}{*}{ (estimate mobility) } & & Car & 2 \\
\hline & & & Local transit & I \\
\hline & & & Pedestrian & 0 \\
\hline & & & I point bonus for 2 options, & \\
\hline & & & 2 points bonus for all options & \\
\hline \multirow[t]{4}{*}{6} & \multirow{4}{*}{$\begin{array}{l}\text { "Do you play any sport?" } \\
\text { (estimate frequency and effort) }\end{array}$} & s & Regular workout & 3 \\
\hline & & & Sporadic or simple activities (walking) & 2 \\
\hline & & & Physiotherapy, focused movements & 1 \\
\hline & & & None & 0 \\
\hline \multirow[t]{4}{*}{7} & \multirow{4}{*}{$\begin{array}{l}\text { "How do you spend your leisure time } \\
\text { with other people?" } \\
\text { (honorary offices, social networks) }\end{array}$} & Isa & Very challenging (honorary office) & 3 \\
\hline & & & Intellectually and socially demanding & 2 \\
\hline & & & Intellectually or socially demanding & I \\
\hline & & & None & 0 \\
\hline \multirow[t]{3}{*}{8} & \multirow{3}{*}{$\begin{array}{l}\text { "Do you play any music instruments?" } \\
\text { (at present not in the past) }\end{array}$} & $\mathrm{ms} / \mathrm{lsa}$ & Regularly and challenging & 2 \\
\hline & & & Amateur/rarely & I \\
\hline & & & None & 0 \\
\hline \multirow[t]{4}{*}{9} & \multirow{4}{*}{$\begin{array}{l}\text { "Are you able to type on } \\
\text { a machine/keyboard?" } \\
\text { (if applicable estimate computer skills) }\end{array}$} & $\mathrm{ms} / \mathrm{lsa}$ & Touch typing & 2 \\
\hline & & & Visually guided & I \\
\hline & & & None & 0 \\
\hline & & & $\begin{array}{l}\text { Up to } 2 \text { points bonus for computer } \\
\text { and Internet skills }\end{array}$ & \\
\hline \multirow[t]{4}{*}{10} & \multirow[t]{4}{*}{ "Do you travel?" } & $\mathrm{m}$ & Independently and often & 2 \\
\hline & & & Only with partner or in a group & I \\
\hline & & & None & 0 \\
\hline & & & $\begin{array}{l}\text { Up to } 2 \text { points bonus for challenging } \\
\text { tours and foreign language use }\end{array}$ & \\
\hline \multirow[t]{3}{*}{11} & \multirow{3}{*}{$\begin{array}{l}\text { "Is there any skilled manual } \\
\text { work or home improvement } \\
\text { activities you carry out?" }\end{array}$} & $\mathrm{ms} / \mathrm{sa}$ & Arts or technical challenging work & 2 \\
\hline & & & Repair work & I \\
\hline & & & None & 0 \\
\hline 12 & "What about gardening?" & Isa & Allotment holder & 2 \\
\hline & & & Front garden/balcony & I \\
\hline & & & None & 0 \\
\hline
\end{tabular}


Table 3 (Continued)

\begin{tabular}{|c|c|c|c|c|}
\hline Item & Questions & Domain & Ranking & Score (points) \\
\hline \multirow[t]{3}{*}{13} & "How often do you write by hand?" & $\mathrm{ms}$ & Often (letters, poems, diary) & 2 \\
\hline & & & Rare (shopping lists) & I \\
\hline & & & None & 0 \\
\hline \multirow[t]{4}{*}{14} & "Do you like to be in the company & Isa/dr & Very sociable, rarely alone & 3 \\
\hline & of other people or do you prefer & & Regularly meet family and friends & 2 \\
\hline & being on your own?" & & Choosy about companions/few contacts & 1 \\
\hline & (estimate frequency of contacts) & & Mostly alone & 0 \\
\hline \multirow[t]{5}{*}{15} & "How are your daily & $\mathrm{dr}$ & Proactive behavior/alternately & 3 \\
\hline & routines structured?" & & Some activities but fixed schedule & 2 \\
\hline & (estimate flexibility) & & Very fixed schedule for basic & $\mathrm{I}$ \\
\hline & & & activities of daily living & \\
\hline & & & Nursing care & 0 \\
\hline \multirow[t]{5}{*}{16} & "How do you feel-are you comfortable & swb & Very good & 4 \\
\hline & with your health situation?" & & Good & 3 \\
\hline & (estimate subjective health condition) & & Acceptable & 2 \\
\hline & & & Bad & 1 \\
\hline & & & Very unsatisfied & 0 \\
\hline \multirow[t]{4}{*}{17} & Fluency of speech & la & Eloquent/responds to various topics & 3 \\
\hline & (no question, ranked by investigator) & & Small deficiencies, but still flexible & 2 \\
\hline & & & Deficiencies in speech and understanding & I \\
\hline & & & Limited comprehension & 0 \\
\hline
\end{tabular}

Abbreviations: Isa, leisure activities; s, sports; swb, subjective wellbeing; la, linguistic abilities; hk, housekeeping; dr, daily routine; ms, manual skills; m, mobility.

ie, subgroup 2a (regular dancing, $\mathrm{n}=30$ ), subgroup $2 \mathrm{~b}$ (regular workout, $\mathrm{n}=22$ ), and subgroup 2c (irregular workout, $\mathrm{n}=21)$. Highest ECQ scores were obtained by the subjects from subgroup $2 \mathrm{a}$ (score $11.86 \pm 2.20$ ), followed by the subjects from subgroup $2 \mathrm{~b}$ (score $11.18 \pm 1.91$ ) and from

Table 4 Four-factor structure of the Everyday Competence Questionnaire: factor analysis for the questionnaire items revealed a four-factor structure

\begin{tabular}{|c|c|c|c|}
\hline Factor & Item & Domain & $\begin{array}{l}\text { Factor } \\
\text { loading }\end{array}$ \\
\hline \multirow[t]{7}{*}{ I } & 9 & $\mathrm{~ms} / \mathrm{lsa}$ & 0.706 \\
\hline & 10 & $\mathrm{~m}$ & 0.683 \\
\hline & I & Isa & 0.633 \\
\hline & 8 & $\mathrm{~ms} / \mathrm{lsa}$ & 0.586 \\
\hline & 7 & Isa & 0.532 \\
\hline & 13 & $\mathrm{~ms}$ & 0.433 \\
\hline & 5 & $\mathrm{~m}$ & 0.413 \\
\hline \multirow[t]{3}{*}{2} & 2 & $\mathrm{hk} / \mathrm{dr}$ & 0.866 \\
\hline & 3 & $\mathrm{hk} / \mathrm{dr}$ & 0.824 \\
\hline & 4 & $\mathrm{hk} / \mathrm{dr}$ & 0.819 \\
\hline \multirow[t]{3}{*}{3} & 14 & $\mathrm{Isa} / \mathrm{dr}$ & 0.834 \\
\hline & 6 & s & 0.562 \\
\hline & II & $\mathrm{ms} / \mathrm{lsa}$ & 0.742 \\
\hline \multirow[t]{4}{*}{4} & 17 & la & 0.746 \\
\hline & 16 & swb & 0.695 \\
\hline & 15 & $\mathrm{dr}$ & 0.602 \\
\hline & 12 & Isa & 0.460 \\
\hline
\end{tabular}

Abbreviations: Isa, leisure activities; s, sports; swb, subjective wellbeing; la, linguistic abilities; hk, housekeeping; dr, daily routine; $\mathrm{ms}$, manual skills; $\mathrm{m}$, mobility. subgroup 2c (score 10.19 \pm 3.37 ). After testing the equality of variance with Levene's test $\left(\mathrm{F}_{(70)}=2,773, P=0.069\right)$, ANOVA revealed a main effect at the $10 \%$ significance level $\left(\mathrm{F}_{(2,70)}=2,818, P=0.067\right)$. The subsequent post hoc analysis (the discriminatory power was adjusted by using the Least Squares Difference test instead of the Bonferroni test) revealed no significant differences between the two regular activity groups (dancing and workout, $P=0.348$ ). There were differences in the performance of subjects with regular and irregular activity; those with regular activity obtained higher

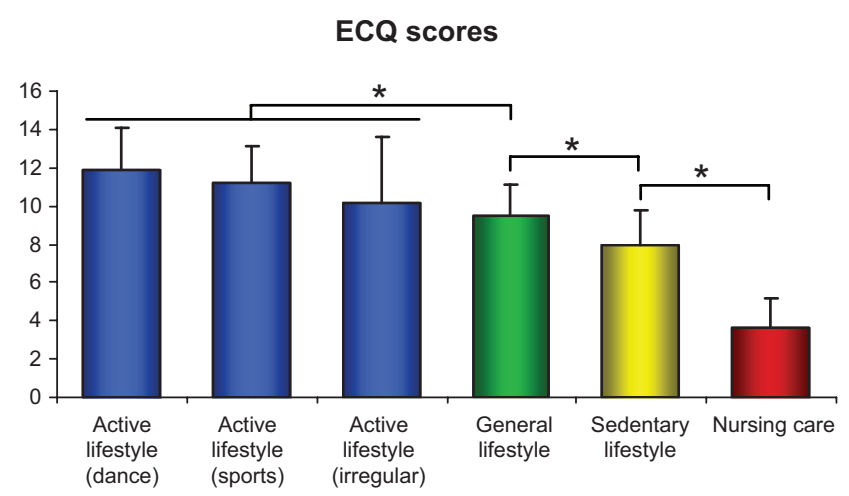

Figure I Everyday Competence Questionnaire scores for all subjects.

Notes: Subjects characterized by an active lifestyle (blue bars) outperformed all other subjects. We found a significant decrease in Everyday Competence Questionnaire scores from data of Group 2 (active lifestyle) over data of Group I (general lifestyle), Group 3 (sedentary lifestyle) and data of Group 4 (nursing care) (Spearman correlation) $r=-0.354, \mathrm{P} \leq 0.00 \mathrm{I}$ ). *Bonferroni post hoc test $\mathrm{P} \leq 0.05$. 
scores $(P=0.047)$. We also found significant differences between subgroup 2a subjects and subgroup 2c subjects, with subgroup 2a subjects obtaining higher scores $(P=0.020)$.

\section{Discussion}

In this study we present a questionnaire which was designed to assess older adults' competence in activities of everyday life. By means of this 17-item questionnaire, which covers the domains of housekeeping, daily routine, manual skills, sports, leisure activities, subjective well-being, and linguistic abilities, it is possible to obtain ratings on the everyday competence of older adults. By administering the questionnaire to a sample of 158 older adults, characterized by different lifestyles, we observed significant group differences that indicated a strong relationship between individual physical activity level and everyday competence. Furthermore, correlation analyses between results obtained from the ECQ and other tests (MMSE, NAA) provided evidence for the reliability of this new questionnaire.

In industrialized civilizations, in order to experience successful aging, one has to engage not only in activities of daily living and IADL-specific activities that ensure personal maintenance, but also in activities that are related to the external environment and social life. Horgas et al stated that people who engage in more than just basic activities, who participate in the external environment, who turn toward others, and engage in self-enriching activities are considered more successful. ${ }^{55}$ These authors differentiated between three types of everyday activities: basic activities, ie, those pertaining to personal maintenance in terms of physical survival; instrumental activities, ie, those referring to personal maintenance in terms of cultural survival; and work, leisure, and social activities, ie, those reflecting agentic, communal, and self-enriching activities. ${ }^{55}$

Leisure activities might be used as a reliable indicator of the changes in the everyday behavior of older adults. Baltes et al stated that during the development of dementia, significant changes occur in everyday behavior. In a longitudinal study based on the Berliner Altersstudie, ${ }^{56}$ the authors showed that subjects suffering from dementia spend less time on hobbies and consumption of media. Age-related reductions in these activities were significantly lower in age-matched healthy subjects. In that study, the authors discuss the usability of activities of daily living and IADL scales for rating everyday competence, as well as the need to estimate everyday competence in terms of leisure and social activities. Their study supports the view that not only pathological but also age-related changes in the physical and mental health of older adults have a significant impact on activities of daily living and eventually on everyday competence. ${ }^{57}$ These notions stress the importance of considering leisure time activities for an adequate estimation of everyday competence in older adults. ${ }^{58}$ Therefore, we incorporated these requirements by including typical leisure activities in the ECQ. Considering the rising life expectancy and the remarkable health conditions even in very old adults, leisure activities might become important indicators of everyday competence among older adults. It is not easy for standard questionnaires to cover the individual activities of modern-day older adults, because the nature of these activities is changing constantly. A few decades ago, it would have been rather uncommon to find older adults taking philosophy classes, taking language vacations in different continents, playing music in an orchestra, or helping to educate trainees in the company they left 20 years earlier. Contemporary assessments of everyday competence have to account for these lifestyle conditions, which are now typically found among older adults.

Our findings support a close positive correlation between physical activity and everyday competence in old age. The ECQ data demonstrate that subjects with an active lifestyle outperform subjects with a general or sedentary lifestyle in terms of everyday competence. These findings are in line with data showing a close association between physical fitness and cognitive performance in healthy older adults..$^{12,14,59,60}$ In the last few years, there has been a significant increase in general interest in maintaining health and cognitive abilities in old age by means of physical exercise programs. ${ }^{60-66} \mathrm{In}$ fact, there is evidence that maintaining physical fitness reduces the risk of mortality among older adults who are active. ${ }^{67}$ In the epidemiologic literature, the concept of "compressed morbidity" was introduced, suggesting that active people can live more disability-free years, ${ }^{68}$ and healthy lifestyles can postpone functional disability. ${ }^{69}$ Other studies have shown that playing intensive sports is not required for cardiovascular benefits. For example, for sedentary older adults, moderate physical activity seems sufficient for improving health significantly. ${ }^{70,71}$ These findings might be particularly important for older adults who are not able to participate in demanding sports but can start moderate physical activities, such as walking. ${ }^{72}$ Dancing might be an attractive alternative to conventional sports because of its high popularity among older adults. Besides physical activity, dancing comprises rhythmic motor coordination, balance and memory, emotions, social interaction, acoustic 
stimulation, and musical experience. ${ }^{73}$ Most studies employing dancing as an intervention among older adults focused on the improvement of cardiovascular parameters, muscle strength, and posture and balance, ${ }^{74-82}$ with a few studies addressing cognitive abilities ${ }^{83,84}$ and the preservation of sensorimotor performance, as well as perceptual abilities. ${ }^{73}$ Accordingly, dancing seems to be the primary activity for ameliorating everyday competence among healthy older adults. ${ }^{85-90}$

\section{Conclusion}

The ECQ presented in this paper might be a useful tool for obtaining ratings of everyday competence among healthy older adults. A sample of 158 subjects, characterized and predefined by different physical activity levels, could be clearly differentiated by evaluating their individual ECQ scores. Our data support the well documented relationship between physical activity and individual everyday competence in old age. In the future, ECQ scores might be used as markers for individual everyday competence to investigate possible correlations with performance-based measures like physical fitness, sensorimotor abilities, and cognition. Further research is needed to investigate the usefulness of the ECQ in nonhealthy populations of older adults.

\section{Acknowledgments}

The work was supported by the Deutsche Forschungsgemeinschaft (Di 334/19-1, HRD; Te 315/4-1, MT), a scholarship from the Research Department of Neuroscience of the RuhrUniversity Bochum to TK, and a scholarship to JCK from the Allgemeiner Deutscher Tanzlehrerverband.

\section{Disclosure}

The authors report no conflicts of interest in this work.

\section{References}

1. Dinse HR. Cortical reorganization in the aging brain. Prog Brain Res. 2006;157:57-80.

2. Klenk J, Rapp K, Buchele G, Keil U, Weiland SK. Increasing life expectancy in Germany: Quantitative contributions from changes in age- and disease-specific mortality. Eur J Public Health. 2007;17(6): 587-592.

3. Oeppen J, Vaupel JW. Demography. Broken limits to life expectancy. Science. 2002;296(5570):1029-1031.

4. Franklin NC, Tate CA. Lifestyle and successful aging: An overview. Am J Lifestyle Med. 2009;3(1):6-11.

5. Stein C, Moritz I. A Life Course Perspective of Maintaining Independence in Older Age. Geneva, Switzerland: World Health Organization; 1999.

6. Crews DE. Human Senescence: Evolutionary and Biocultural Perspectives. New York, NY: Cambridge University Press; 2003.

7. Mahncke HW, Connor BB, Appelman J, et al. Memory enhancement in healthy older adults using a brain plasticity-based training program: A randomized, controlled study. Proc Natl Acad Sci U S A. 2006; 103(33):12523-12528.
8. Singh AS, Chin APMJ, Bosscher RJ, van Mechelen W. Cross-sectional relationship between physical fitness components and functional performance in older persons living in long-term care facilities. BMC Geriatr. 2006;6:4.

9. Buchner DM, Larson EB, Wagner EH, Koepsell TD, de Lateur BJ. Evidence for a non-linear relationship between leg strength and gait speed. Age Ageing. 1996;25(5):386-391.

10. Rowe JW, Kahn RL. Successful aging. Gerontologist. 1997;37(4): 433-440.

11. Motta M, Bennati E, Ferlito L, Malaguarnera M, Motta L. Successful aging in centenarians: Myths and reality. Arch Gerontol Geriatr. 2005; 40(3):241-251.

12. Colcombe SJ, Kramer AF, McAuley E, Erickson KI, Scalf P. Neurocognitive aging and cardiovascular fitness: Recent findings and future directions. J Mol Neurosci. 2004;24(1):9-14.

13. McAuley E, Kramer AF, Colcombe SJ. Cardiovascular fitness and neurocognitive function in older adults: A brief review. Brain Behav Immun. 2004;18(3):214-220.

14. Colcombe SJ, Kramer AF, Erickson KI, et al. Cardiovascular fitness, cortical plasticity, and aging. Proc Natl Acad Sci U SA. 2004;101(9): 3316-3321.

15. Ball K, Berch DB, Helmers KF, et al. Effects of cognitive training interventions with older adults: A randomized controlled trial. JAMA. 2002;288(18):2271-2281.

16. Willis SL, Tennstedt SL, Marsiske M, et al. Long-term effects of cognitive training on everyday functional outcomes in older adults. JAMA. 2006;296(23):2805-2814.

17. Galli RL, Shukitt-Hale B, Youdim KA, Joseph JA. Fruit polyphenolics and brain aging: Nutritional interventions targeting age-related neuronal and behavioral deficits. Ann N Y Acad Sci. 2002;959:128-132.

18. Joseph JA, Shukitt-Hale B, Casadesus G. Reversing the deleterious effects of aging on neuronal communication and behavior: Beneficial properties of fruit polyphenolic compounds. Am J Clin Nutr. 2005;81(Suppl 1): 313S-316S.

19. Twomey LT, Taylor JA. Old age and physical capacity: Use it or lose it. Aust J Physiother. 1984;30(4):115-120.

20. Cassel CK. Use it or lose it: Activity may be the best treatment for aging. JAMA. 2002;288(18):2333-2335.

21. Diehl M. Everyday competence in later life: Current status and future directions. Gerontologist. 1998;38(4):422-433.

22. Willis SL. Cognition and everyday competence. Ann Rev Gerontol Geriat. Vol 11. New York, NY: Springer; 1991.

23. Baltes MM, Carstensen L. Gutes Leben im Alter: Überlegungen zu einem prozessorientierten Metamodell erfolgreichen Alterns. Psychologische Rundschau. 1996;47:199-215.

24. Wahl HW. Every day competence: A construct in search for an identity. Z Gerontol Geriatr. 1998;31(4):243-249. German.

25. Cornelius SW, Caspi A. Everyday problem solving in adulthood and old age. Psychol Aging. 1987;2(2):144-153.

26. Diehl M, Willis SL, Schaie KW. Everyday problem solving in older adults: Observational assessment and cognitive correlates. Psychol Aging. 1995;10(3):478-491.

27. Marsiske M, Willis SL. Dimensionality of everyday problem solving in older adults. Psychol Aging. 1995;10(2):269-283.

28. Park DC.Applied cognitive aging research. In: Craik FIM, Salthouse TA, editors. The Handbook of Aging and Cognition. Hillsdale, NY: Erlbaum; 1992.

29. Brennan M, Horowitz A, Su YP. Dual sensory loss and its impact on everyday competence. Gerontologist. 2005;45(3):337-346.

30. Brennan M, Su YP, Horowitz A. Longitudinal associations between dual sensory impairment and everyday competence among older adults. $J$ Rehabil Res Dev. 2006;43(6):777-792.

31. Chou KL. Everyday competence and depressive symptoms: Social support and sense of control as mediators or moderators? Aging Ment Health. 2005;9(2):177-183.

32. Allaire JC, Willis SL. Competence in everyday activities as a predictor of cognitive risk and mortality. Neuropsychol Dev Cogn B Aging Neuropsychol Cogn. 2006;13(2):207-224. 
33. Willis SL. Everyday problem solving. In: Birren JE, Schaie KW, editors. Handbook of the Psychology of Aging. 4th ed. New York, NY: Academic Press; 1996.

34. Baum C, Edwards DF. Cognitive performance in senile dementia of the Alzheimer's type: The Kitchen Task Assessment. Am J Occup Ther. 1993;47(5):431-436

35. Glass TA. Conjugating the "tenses" of function: Discordance among hypothetical, experimental, and enacted function in older adults. Gerontologist. 1998;38(1):101-112.

36. Moore DJ, Palmer BW, Patterson TL, Jeste DV. A review of performance-based measures of functional living skills. J Psychiatr Res. 2007;41(1-2):97-118.

37. Granger CV. Advances in functional assessment for medical rehabilitation. Top Geriatr Rehabil. 1986;1:59-74

38. Tyron WW. Behavioral observation. In: Bellack AS, Hersen M, editors. Behavioral Assessment: A Practical Handbook. Needham Heights, MA: Allyn \& Bacon; 1998.

39. Magaziner J, Zimmerman SI, Gruber-Baldini AL, Hebel JR, Fox KM. Proxy reporting in five areas of functional status. Comparison with self-reports and observations of performance. Am J Epidemiol. 1997; $146(5): 418-428$.

40. Kalisch T, Wilimzig C, Kleibel N, Tegenthoff M, Dinse HR. Age-related attenuation of dominant hand superiority. PLoS One. 2006;1:e90.

41. Dinse HR, Kleibel N, Kalisch T, Ragert P, Wilimzig C, Tegenthoff M. Tactile coactivation resets age-related decline of human tactile discrimination. Ann Neurol. 2006;60(1):88-94.

42. Dinse HR, Kalisch T, Ragert P, Pleger B, Schwenkreis P, Tegenthoff M. Improving human haptic performance in normal and impaired human populations through unattended activation-based learning. ACM Trans Appl Percept. 2005;2(2):71-88.

43. Kalisch T, Tegenthoff M, Dinse HR. Repetitive electric stimulation elicits enduring improvement of sensorimotor performance in seniors. Neural Plast. 2010;2010:690531.

44. Kattenstroth JC, Kalisch T, Holt SK, Tegenthoff M, Dinse HR. Beneficial effects of a six-months dance class on sensorimotor and cognitive performance of elderly individuals. Vol 180.8. Chicago, IL: Society for Neuroscience; 2009: Neuroscience Meeting Planner, online.

45. Kalisch T, Kattenstroth JC, Tegenthoff M, Dinse HR. Repetitive electric stimulation as an intervention to enhance sensorimotor functions in long-term chronic stroke patients. Vol 769.3 Chicago, IL: Society for Neuroscience; 2009:Neuroscience Meeting Planner, online.

46. Schwenkreis P, El Tom S, Ragert P, Pleger B, Tegenthoff M, Dinse HR Assessment of sensorimotor cortical representation asymmetries and motor skills in violin players. Eur J Neurosci. 2007;26(11): 3291-3302.

47. Liepert J, Tegenthoff M, Malin JP. Changes of cortical motor area size during immobilization. Electroencephalogr Clin Neurophysiol. 1995; 97(6):382-386.

48. Lissek S, Wilimzig C, Stude P, et al. Immobilization impairs tactile perception and shrinks somatosensory cortical maps. Curr Biol. 2009; 19(10):837-842.

49. Folstein MF, Folstein SE, McHugh PR. "Mini-mental state". A practical method for grading the cognitive state of patients for the clinician. J Psychiatr Res. 1975;12(3):189-198.

50. Tombaugh TN, McIntyre NJ. The Mini-Mental State Examination: A comprehensive review. J Am Geriatr Soc. 1992;40(9): 922-935.

51. Oswald W, Fleischmann U. Das Nürnberger Altersinventar (Kurz: NAI). Göttingen: Verlag Hogrefe; 1997.

52. Brosius F. SPSS 12. Bonn: Mtip-Verlag; 2004.

53. Kaiser H, Rice J, Little Jiffy, Mark IV. Educ Psychol Meas. 1974(34): 111-117.

54. Backhaus K, Erichson B, Plinke W, Weiber R. Multivariate Analysemethoden. Berlin: Springer; 2006.

55. Horgas AL, Wilms HU, Baltes MM. Daily life in very old age: Everyday activities as expression of successful living. Gerontologist. 1998;38(5) $556-558$.
56. Baltes MM, Maas I, Wilms HU, Borchelt M. Alltagskompetenz im Alter: Theoretische Überlegungen und empirische Befunde. In: Mayer KU, Baltes PB, editors. Die Berliner Altersstudie. Berlin: Akademie Verlag; 1996.

57. Wilms HU, Baltes MM, Kanowski S. Dementias and daily competence: Effects beyond ADL and IADL. Z Gerontol Geriatr. 1998;31(4): 263-270. German.

58. Tesch-Romer C, Wilms HU. Every day competence. Z Gerontol Geriatr. 1998;31(4):241-242. German.

59. Schäfer S, Huxhold O, Lindenberger U. Healthy mind in healthy body? A review of sensorimotor-cognitive interdependencies in old age. Eur Rev Aging Phys Act. 2006;3(2):45-54.

60. Sumic A, Michael YL, Carlson NE, Howieson DB, Kaye JA. Physical activity and the risk of dementia in oldest old. J Aging Health. 2007; 19(2):242-259.

61. Lidor R, Miller U, Rotstein A. Is research on aging and physical activity really increasing? A bibliometric analysis. J Aging Phys Act. 1999; 7: 182-195.

62. Kramer AF, Hahn S, Cohen NJ, et al. Ageing, fitness and neurocognitive function. Nature. 1999;400(6743):418-419.

63. Colcombe SJ, Erickson KI, Scalf PE, et al. Aerobic exercise training increases brain volume in aging humans. J Gerontol A Biol Sci Med Sci. 2006;61(11):1166-1170.

64. Deley G, Kervio G, van Hoecke J, Verges B, Grassi B, Casillas JM. Effects of a one-year exercise training program in adults over 70 years old: A study with a control group. Aging Clin Exp Res. 2007;19(4): 310-315.

65. Hillman $\mathrm{CH}$, Erickson KI, Kramer AF. Be smart, exercise your heart: Exercise effects on brain and cognition. Nat Rev Neurosci. 2008;9(1): 58-65.

66. Voelcker-Rehage C, Godde B, Staudinger UM. Physical and motor fitness are both related to cognition in old age. Eur J Neurosci. 2010;31(1): $167-176$.

67. CDC. Physical Activity and Health: A Report of the Surgeon General. Atlanta, GA: US Department of Health and Human Services, Public Health Service, CDC, National Center for Chronic Disease Prevention and Health Promotion; 1996.

68. Leveille SG, Guralnik JM, Ferrucci L, Langlois JA. Aging successfully until death in old age: Opportunities for increasing active life expectancy. Am J Epidemiol. 1999;149(7):654-664.

69. Vita AJ, Terry RB, Hubert HB, Fries JF. Aging, health risks, and cumulative disability. N Engl J Med. 1998;338(15):1035-1041.

70. Bauman AE, Smith BJ. Healthy ageing: What role can physical activity play? Med J Aust. 2000;173(2):88-90.

71. Blair SN, Kohl HW 3rd, Barlow CE, Paffenbarger RS Jr, Gibbons LW, Macera CA. Changes in physical fitness and all-cause mortality. A prospective study of healthy and unhealthy men. JAMA. 1995; 273(14):1093-1098.

72. Kriska A. Physical activity and the prevention of Type 2 diabetes mellitus: How much for how long? Sports Med. 2000;29(3): 147-151.

73. Kattenstroth JC, Kolankowska I, Kalisch T, Dinse HR. Superior sensory, motor, and cognitive performance in elderly individuals with multi-year dancing activities. Front Aging Neurosci. 2010;2.

74. Hopkins DR, Murrah B, Hoeger WW, Rhodes RC. Effect of low-impact aerobic dance on the functional fitness of elderly women. Gerontologist. 1990;30(2):189-192.

75. Estivill M. Therapeutic aspects of aerobic dance participation. Health Care Women Int. 1995;16(4):341-350.

76. Crotts D, Thompson B, Nahom M, Ryan S, Newton RA. Balance abilities of professional dancers on select balance tests. J Orthop Sports Phys Ther. 1996;23(1):12-17.

77. Shigematsu R, Chang M, Yabushita N, et al. Dance-based aerobic exercise may improve indices of falling risk in older women. Age Ageing 2002;31(4):261-266.

78. Federici A, Bellagamba S, Rocchi MB. Does dance-based training improve balance in adult and young old subjects? A pilot randomized controlled trial. Aging Clin Exp Res. 2005;17(5):385-389. 
79. Hui E, Chui BT, Woo J. Effects of dance on physical and psychological well-being in older persons. Arch Gerontol Geriatr. 2009;49(1): e45-e50.

80. Kreutz G. Does partnered dance promote health? The case of tango Argentino. J R Soc Promot Health. 2008;128(2):79-84.

81. Zhang JG, Ishikawa-Takata K, Yamazaki H, Morita T, Ohta T. Postural stability and physical performance in social dancers. Gait Posture. 2008; 27(4):697-701.

82. Sofianidis G, Hatzitaki V, Douka S, Grouios G. Effect of a 10-week traditional dance program on static and dynamic balance control in elderly adults. J Aging Phys Act. 2009;17(2):167-180.

83. Verghese J. Cognitive and mobility profile of older social dancers. J Am Geriatr Soc. 2006;54(8):1241-1244.

84. Alpert PT, Miller SK, Wallmann H, et al. The effect of modified jazz dance on balance, cognition, and mood in older adults. J Am Acad Nurse Pract. 2009;21(2):108-115.

85. Earhart GM. Dance as therapy for individuals with Parkinson disease. Eur J Phys Rehabil Med. 2009;45(2):231-238.
86. Hackney ME, Kantorovich S, Levin R, Earhart GM. Effects of tango on functional mobility in Parkinson's disease: A preliminary study. J Neurol Phys Ther. 2007;31(4):173-179.

87. Hackney ME, Earhart GM. Effects of dance on gait and balance in Parkinson's disease: A comparison of partnered and nonpartnered dance movement. Neurorehabil Neural Repair. 2009;24(4):384-392.

88. Hackney ME, Earhart GM. Effects of dance on movement control in Parkinson's disease: A comparison of Argentine tango and American ballroom. J Rehabil Med. 2009;41(6):475-481.

89. Hokkanen L, Rantala L, Remes AM, Harkonen B, Viramo P, Winblad I. Dance and movement therapeutic methods in management of dementia: A randomized, controlled study. J Am Geriatr Soc. 2008; 56(4):771-772.

90. Hackney ME, Earhart GM. Social partnered dance for people with serious and persistent mental illness: A pilot study. J Nerv Ment Dis. 2010;198(1):76-78.
Clinical Interventions in Aging

\section{Publish your work in this journal}

Clinical Interventions in Aging is an international, peer-reviewed journal focusing on evidence-based reports on the value or lack thereof of treatments intended to prevent or delay the onset of maladaptive correlates of aging in human beings. This journal is indexed on PubMed Central, MedLine, the American Chemical Society's 'Chemical Abstracts Ser-

\section{Dovepress}

vice' (CAS), Scopus and the Elsevier Bibliographic databases. The manuscript management system is completely online and includes a very quick and fair peer-review system, which is all easy to use. Visit http://www.dovepress.com/testimonials.php to read real quotes from published authors. 